Bojan Mevlja.

Univerza na Primorskem,

Fakulteta za management,

Slovenija

bojan.mevlja@fm-kp.si

Dane Podmenik

Zavod Eko-Humanitatis,

Slovenija

dane.podmenik@gmail.com

\section{Vloga nevladnih organizacij pri regionalnem razvoju Slovenije: primer obalno-kraške regije}

Namen prispevka je osvetliti pomen nevladnih organizacij (NVO) pri regionalnem razvoju na primeru obalno-kraške regije. Nevladne organizacije se v razvoj regije vključujejo s predlogi skupnih projektov in udeležbo v odborih, kjer skupaj s predstavniki gospodarstva in lokalnih skupnosti oblikujejo razvojne prioritete regije in pripravljajo Regionalni razvojni program (RRP). Dosedanje vključevanje in vpliv NVO na pripravo RRP lahko ocenimo kot pozitivno, saj je program dal velik poudarek vsebinam, ki so jih nevladne organizacije promovirale in zagovarjale. $\mathrm{V}$ prispevku je izpostavljen tudi pomen socialnega podjetništva, ki bi lahko izdatno pripomoglo k trajnostnemu razvoju regije, zlasti podeželja, in h krepitvi nevladnega sektorja.

Ključne besede: obalno-kraška regija, trajnostni razvoj, nevladne, organizacije, podeželje, socialno podjetništvo

\section{The Role of Non-Governmental Organizations in the Regional Development of Slovenia: The Case of the Coastal-Karst Region}

The purpose of this paper is to shed light on the importance of nongovernmental organizations (NGOS) in regional development, in the case of the Obalno-kraška region. Non-governmental organizations are involved in the development of the region through proposals for joint projects and participation in committees, where, together with representatives of the economy and local communities, they formulate the development priorities of the region and prepare the Regional Development Programme (RDP). The involvement and influence of NGOS on the preparation of the RDP so far can be assessed as positive, as the programme places great emphasis on the content promoted and advocated by non-governmental organizations. The article also highlights the importance of social entrepreneurship, which could make a significant contribution to the sustainable development of the region, especially in rural areas and the strengthening of the non-governmental sector.

Keywords: Coastal-Karst region, sustainable development, non-governmental organizations, rural areas, social entrepreneurship

(cc) BY-SA https://doi.org/10.26493/1854-4231.16.47-51

\section{Uvod}

Nevladne organizacije (NVO) so organizacije, ki jih lahko na lastno pobudo ustanovi vsak izmed nas. V vseh pogledih delujejo neodvisno od države in imajo nekaj temeljnih značilnosti. So neprofitne, večinoma prostovoljne in prav vse morajo imeti neko obliko pravne osebe. V Sloveniji so to prvenstveno društva, ustanove in (zasebni) zavodi (Forbici idr. 2010). NVO predstavljajo enega izmed treh glavnih stebrov sodobne družbe, $s$ povsem lastno identiteto in socialno funkcijo, ne- odvisno od državnega in gospodarskega sektorja (Vrečko 2003, 20).

NVo spadajo med neprofitne organizacije, ki večinoma niso ustanovljene zaradi ustvarjanja dobička, ampak zato, da pomagajo pri trajnem zagotavljanju storitev in dobrin za uspešno delovanje družbe. Iz tega sledi, da je smisel obstoja neprofitnih organizacij delovanje v splošnem družbenem interesu oziroma delovanje $\mathrm{v}$ splošne družbenokoristne namene (Kolarič 2002, 29). Nevladne organizacije predstavljajo tudi po- 
sebno vrsto kulturne in institucionalne osnove. Ker je njihova zaveza posebno družbeno poslanstvo, njihove člane v prvi vrsti zanimata in motivirata organizacijsko poslanstvo in želja, da bi prispevali, da bi bil svet še boljši. Prav tako so nevladne organizacije manj hierarhične od drugih institucij (Leete 2000, 428; De Cooman idr. 2011, 302).

Zasebni neprofitni in nevladni sektor predstavlja, po mnenju mnogih avtorjev, pomemben instrument demokratizacije in pluralizacije odnosov, razširitve individualnih možnosti in svobodne izbire posameznikov ter povečanja aktivne participacije v moderni družbi (Črnak-Meglič in Vojnovič 1997, 153). Po Putnamu (1993) NVO predstavljajo enega ključnih indikatorjev zalog socialnega kapitala, ki deluje kot generator družbenega ter ekonomskega razvoja. Pomembno je poudariti, da imajo NVO zelo pomembno vlogo v okviru vedno bolj uveljavljajoče se paradigme (neo)endogenega razvoja podeželja, na kateri temeljijo novejše razvojne politike podeželja (Potočnik Slavič 2008). Tudi v obalno-kraški regiji NVo predstavljajo enega izmed pomembnih deležnikov pri njenem razvoju.

\section{Stanje in izzivi nevladnih organizacij v obalno-kraški regiji}

Obalno-kraško statistično regijo sestavljajo občine Ankaran, Divača, Hrpelje-Kozina, Izola, Komen, Koper, Piran in Sežana. Število prebivalcev regije znaša 113.961, kar predstavlja $5 \%$ vseh prebivalcev Republike Slovenije (Statistični urad Republike Slovenije 2018). Po zadnjih podatkih (glej https://www.ajpes.si) skupno v Sloveniji deluje 27.868 nevladnih organizacij, medtem ko v obalno-kraški regiji deluje okrog 1.600 nevladnih organizacij, kar prestavlja okrog $6 \%$ vseh nevladnih organizacij v Sloveniji. Te organizacije imajo le 260 zaposlenih, kar predstavlja o,5\% delovno aktivnega prebivalstva $\mathrm{v}$ regiji in okrog 30 milijonov evrov prihodkov. Večinoma gre za manjše NVo, ki delujejo v (zelo) »omejenem« obsegu ali pa so celo neaktivne. Tako $15 \%$ vseh društev v letu 2020 ni ustvarilo nobenih prihodkov, tretjina pa se uvršča $\mathrm{v}$ razred $\mathrm{z}$ ustvarjenimi letnimi prihodki do 5.000 EUR.

Prvi sistematični poskusi razvoja nevladnega sektorja v obalno-kraški regiji segajo v leto $2009 \mathrm{z}$ vzpostavitvijo Regijskega stičišča za nevladne organizacije ter leto 2012, ko je bila ustanovljena Mreža nevladnih organizacij obalno-kraške regije. To sta prostovoljni in neformalni združenji s ciljem oblikovanja in zagovarjanja interesov ne- vladnega sektorja v razmerju do vseh ravni oblasti in javnosti (Središče Rotunda, primorski družbeni center 2012).

Po podatkih Strategije razvoja nevladnega sektorja v obalno-kraški regiji 2013-2019 (Središče Rotunda 2012) imajo občine $\mathrm{v}$ regiji različen odnos do nevladnih organizacij. Vseh sedem občin omogoča sofinanciranje programov oziroma projektov z namenskimi proračunskimi postavkami za posamezna področja. Občine namenjajo nevladnim organizacijam 2,5-4-odstotni delež proračuna. Med vsemi ima le Občina Piran sklenjen sporazum o sodelovanju med občino in nevladnimi organizacijami. Razen Mestne občine Koper vse občine omogočajo brezplačen najem prostorov. Poleg tega vse občine razen Mestne občine Koper omogočajo brezplačna oglaševalska mesta za oglaševanje nepridobitnih dejavnosti. Občine Divača, Komen, Hrpelje-Kozina in Sežana omogočajo delno večletno financiranje programov nevladnih organizacij. Nevladne organizacije ugotavljajo, da so med drugim nepogrešljive zaradi velikega posluha za ranljivejše in šibkejše v družbi, posluha za socialno ogrožene skupine, širokega področja delovanja, zagotavljanja raznolikosti storitev, usmerjenosti $\mathrm{v}$ uporabnike. $\mathrm{Na}$ drugi strani pa se soočajo $z$ odvisnostjo od pridobivanja sredstev in financiranja, s pomanjkanjem prostorov in opreme za delovanje, samozadostnostjo in $z$ nepoznavanjem prednosti povezovanja ter $\mathrm{s}$ preobremenjenostjo $\mathrm{z}$ birokracijo. Da bi to stanje izboljšali, so si nevladne organizacije $\mathrm{v}$ regiji $\mathrm{v}$ tej strategiji zadale dva strateška cilja, in sicer povečanje zaposljivosti in finančnih prihodkov nevladnega sektorja $\mathrm{v}$ regiji do leta 2019. Da bi to dosegle, so si zastavile strateške izzive na področju krepitve zagovorništva in civilnega dialoga, krepitve izvajanja storitev in sodelovanja.

Da bi NVo lažje dosegle prej omenjena strateška cilja, so si prizadevale za umestitev svojih vsebin $v$ Regionalni razvojni program (RRP) in s tem jasno pokazati na pomembnost nevladnega sektorja ter posledično umestitve sektorja $\mathrm{v}$ razvoj regije, kjer naj nimata mesta le gospodarstvo in javni sektor, ampak tudi nevladni sektor.

\section{Vključevanje nevladnih organizacij v razvoj regije}

Zakon o spodbujanju skladnega regionalnega razvoja (ZSRR-2) (2011), ki je predpogoj za pripravo RRP v Sloveniji in razvoj regij, NVO umešča kot enega izmed deležnikov razvoja regije. Tako zakon nalaga občinam, združenjem gospodarskih 
dejavnosti, samoupravnim narodnim skupnostim ter nevladnim organizacijam, da se pri uresničevanju svojih razvojnih interesov povezujejo in skupaj sprejemajo odločitve v skladu $\mathrm{z}$ načelom trajnostnega ter regionalnega razvoja. Regionalno sodelovanje vključuje razvojne mreže lokalnih in regionalnih javnih, zasebnih in neprofitnih organizacij, ki se želijo ukvarjati z višjimi ravnmi upravljanja ter osredinjati svoja ekonomska razvojna prizadevanja $\mathrm{v}$ korist regije kot celote (McCarthy 2003, 140).

Nevladne organizacije v družbi opravljajo vsaj tri pomembne funkcije: politično - pomenijo obliko participacije državljanov pri upravljanju države in družbe; ekonomsko - pomenijo način za aktiviranje dodatnih virov v materialni (donacije v denarju) ali nematerialni obliki (vložek prostovoljcev, donacije v naravi); socialno - zagotavljajo dopolnilne ali alternativne načine zadovoljevanja potreb uporabnikov (Črnak-Meglič in Rakar 2009, 2). Prav tako nevladne organizacije v družbeni sistem prinašajo vrednote solidarnosti, ki jih druga dva sektorja, to sta javni in gospodarski, ne predstavljata. Država namreč deluje na podlagi instrumenta moči, gospodarski oziroma profitni sektor pa na podlagi denarja (Kolarič 1997, 17).

Prav zaradi vsega opisanega je pomembno, da imajo tudi nevladne organizacije $\mathrm{v}$ družbi svoj glas. Po zakonu ima nevladni sektor svoje predstavnike $v$ najpomembnejšemu regionalnemu organu, tj. v Razvojnem svetu regije, ki vodi in usmerja pripravo ter potrjuje RRP. Poleg tega sodeluje z regijami drugih držav, sklepa dogovore za razvoj regije, sodeluje $v$ teritorialnem razvojnem dialogu in spremlja izvajanje RRP.

$\mathrm{Z}$ namenov krepitve razvojnega sodelovanja med NVO in njihovega aktivnega vključevanja V pripravo nastajajočega RRP je bila v letu 2012 oblikovana Mreža NVo obalno-kraške regije. Prvi izziv mreže je predstavljala zasnova skupnih razvojnih projektov za umestitev v RRP. Rezultat je bil pozitiven, saj je bilo pripravljenih več predlogov kakovostnih projektov, ki odgovarjajo na potrebe regije. Med te sodijo:

- vzpostavitev sheme globalnih nepovratnih sredstev za sofinanciranje manjših projektov z namenom skupnega reševanja lokalnih težav,

- družbeni center, ki bo deloval na področjih mladine, kulture in ostalih družbenih dejavnosti,

- center za razvoj nevladnih organizacij in socialnega podjetništva, ki bo namenjen kre- pitvi podpornega okolja za razvoj nevladnih organizacij in socialnega podjetništva,

- center za trajnostno soupravljanje in razvoj podeželja, katerega namen je spodbujanje ekološkega kmetijstva, ekoturizma in socialnega podjetništva, ustvarjanje "zelenih" delovnih mest in produktov, povezovanje akterjev podeželja ter skrb za varovanje naravne in kulturne dediščine, in

- regionalni karierni center, ki bo zagotavljal boljše pogoje za usposabljanja, iskanje zaposlitvenih možnosti in posledično nove zaposlitve mladih.

V času priprave RRP so predstavniki NVO aktivno sodelovali na srečanjih tematskih odborov, kjer so skupaj s predstavniki gospodarstva in lokalnih skupnosti analizirali stanje ter potrebe $\mathrm{v}$ regiji in oblikovali razvojne prioritete, ki so bile umeščene v RRP. Ker so si NVO želele iskati rešitve za celotno regijo, so si zato prizadevale za iskanje takšnih skupnih prioritetnih projektov regije, ki bi resnično odgovarjali na njene potrebe. Prav tako so si NVo želele partnerskega sodelovanja pri črpanju sredstev za razvoj regije.

\section{Socialno podjetništvo: izziv za krepitev nevladnega sektorja in trajnostni razvoj (podeželja) regije}

V okviru doseganja ciljev trajnostnega razvoja regij in podeželja lahko pomembno vlogo odigra socialno podjetništvo, ki temelji na aktivaciji in rabi lokalnih virov ter potencialov. Pri tem gre za povezovanje tradicionalnih dejavnosti in znanj (npr. kmetijstvo, obrt, kulinarika) in "modernejših" storitev podeželja (npr. podjetništvo, turizem, oskrba starejših, varstvo okolja) (Podmenik idr. 2013, 4).

Pregled evidence socialnih podjetij (Ministrstvo za gospodarski razvoj in tehnologijo 2021) pokaže, da so v Sloveniji prav NVo nosilke razvoja socialnega podjetništva, saj od skupno 274 socialnih podjetij kar 167 predstavljajo NVO. To pomeni, da socialno podjetništvo prinaša mnoge potenciale za krepitev in razvoj sektorja NVO.

V okviru programa Leader, sofinanciranega iz Evropskega kmetijskega sklada za razvoj podeželja, so Središče Rotunda, Zavod Eko-Humanitatis in Združenje ekoloških kmetov izvajali projekt »Socialno podjetništvo - nove priložnosti zaposlovanja in trajnostni razvoj podeželja Istre«. Projekt je predstavljal prve korake v smeri promocije in spodbujanja razvoja socialnega podjetništva na območju slovenske Istre oziroma obalno- 
kraške regije. Veliko zanimanje lokalnega prebivalstva za projektne aktivnosti dokazuje, da v socialnem podjetništvu mnogi vidijo nove priložnosti. V okviru projekta je bila izvedena tudi Analiza potencialov $z$ akcijskim načrtom in ukrepi razvoja socialnega podjetništva na podeželju Slovenske Istre (LAS Istra) (Podmenik idr. 2013). Ta je bila usmerjena $\mathrm{v}$ preučevanje in opredelitev odnosa in vloge lokalnih skupnosti, podpornih organizacij in nevladnih organizacij pri razvoju socialnega podjetništva, potencialov socialnega podjetništva, ključnih razvojnih ciljev ter aktivnosti oziroma ukrepov za spodbujanje razvoja socialnega podjetništva na območju slovenske Istre.

Rezultati analize so pokazali, da je pri razvoju socialnega podjetništva na lokalni oziroma regionalni ravni zelo pomembna vloga občin, ki pa bi morala biti aktivnejša (Podmenik idr. 2013, 42). Obstoječe podporne organizacije se aktivneje ne ukvarjajo s socialnim podjetništvom in to področje tudi razmeroma slabo poznajo, kar je predpogoj za delovanje podpornega okolja za socialno podjetništvo. Tukaj izstopa socialno podjetje Središče Rotunda, Koper, so. p., ki ga lahko označimo kot najaktivnejšega deležnika pri spodbujanju socialnega podjetništva v regiji. Nasprotno pa so nekatere organizacije izrazito pasivne, čeprav imajo možnosti oziroma vzvode za aktivnejše udejstvovanje (Podmenik idr. 2013, 45).

Če se osredotočimo na odnos nevladnih organizacij do socialnega podjetništva, je analiza pokazala, da so njihovi predstavniki v glavnem seznanjeni s konceptom socialnega podjetništva, nekoliko manj pa poznajo zakonodajo na tem področju. Pri nadaljnjem razvoju socialnega podjetništva v regiji se jim zdi ključna vloga lokalnih skupnosti ter nevladnega sektorja. Večina meni, da bi bila pri spodbujanju socialnega podjetništva potrebna aktivnejša vloga oziroma podpora s strani občin. Velika večina nevladnih organizacij vidi potrebo po vzpostaviti celovitega podpornega okolja. Kot najpotrebnejše aktivnosti tovrstnega »inkubatorja za socialno podjetništvo« lahko izpostavimo: strokovno pomoč oziroma podporo na področju trženja, finančnih virov (posojila, nepovratna sredstva ipd.) in mreženja oziroma iskanja partnerjev. Zelo pozitivno je dejstvo, da polovica vprašanih nevladnih organizacij namerava $\mathrm{v}$ bližnji prihodnosti (obdobje do treh let) delovati na področju socialnega podjetništva, kar pomeni, da lahko pričakujemo razvoj novih projektov in storitev socialnega podjetništva ter posledično krepitev sektorja NVO (Podmenik idr. 2013, 39).
Ena od ključnih ugotovitev raziskave je, da ima podeželje mnoge (neizkoriščene) priložnosti za razvoj dejavnosti oziroma storitev socialnega podjetništva, med katerimi najbolj izstopata ekološka pridelava in predelava. Poleg ekološkega kmetijstva so potenciali še $\mathrm{v}$ turizmu, trgovini z lokalnimi ekološkimi živili, socialnem ter družinskem varstvu in varovanju ter urejanju okolja (Podmenik idr. 2013, 49).

\section{Sklep}

Podatki kažejo, da je NVo sektor v regiji, z vidika zalog človeškega, socialnega in finančnega kapitala, podhranjen in se srečuje $z$ mnogimi izzivi. Prav tako je glas NVo premalo upoštevan pri pripravi lokalnih oziroma regionalnih politik in ukrepov. Občine v mnogih primerih nimajo posluha za (razvojne) predloge NVO in jih ne obravnavajo kot pomembnega deležnika razvoja lokalne skupnosti. Tukaj je potreben tudi kritičen pogled na NVO, saj (do sedaj) ni prihajalo do potrebnega medsebojnega aktivnega povezovanja, kar bi pripomoglo k njihovemu večjemu vplivu.

$Z$ vidika izpostavljenih problematik korak naprej predstavlja možnost aktivnega vključevanja NVO v procese sooblikovanja regionalnega razvoja oziroma RRP, ki ga omogoča nova zakonodaja. Le to lahko izdatno pripomore k krepitvi sektorja NVO in doseganju dveh ključnih ciljev, opredeljenih v Strategiji razvoja nevladnega sektorja v obalno-kraški regiji - dvigu zaposlenosti in finančnih virov v NVO. Zato je znotraj NVO prišlo do intenzivnega mreženja in priprave skupnih predlogov razvojnih projektov za umestitev V RRP.

Prav pomanjkljivo aktivno sodelovanje med regionalnimi oziroma lokalnimi deležniki (občine, razvojne agencije, javni zavodi, NVO, univerza, podporne organizacije ter ekonomski sektor) lahko označimo kot enega glavnih zavirajočih dejavnikov trajnostnega razvoja regije in podeželja. Zato lahko ugotovitvam, da je za Slovenijo značilen pomanjkljiv socialni kapital v obliki zaupanja in kooperacije, kar negativno vpliva na nastajanje t.i. projektnih tipov organiziranja, ki so (pred)pogoj za uspešno razvojno (so)delovanje (Adam in Rončević 2004), na primeru obalnokraške regije pritrdimo. $V$ tem kontekstu bi po našem mnenju tudi (preveč samozadostne) občine morale prevzeti aktivnejšo razvojno-povezovalno vlogo, saj bi se tako po Adamu idr. (2010) možnosti za (inovativni) preboj povečale.

Dosedanje vključevanje in vpliv NVO na pripravo RRP lahko ocenimo kot pozitivna. Predlog 
RRP daje velik poudarek vsebinam, ki so jih NVO skozi postopek priprave RRP promovirale in zagovarjale. Med drugim so to: krepitev sektorja NVO, ekološko kmetijstvo, zelene oblike turizma, aktivnejši pristop $\mathrm{k}$ varovanju narave in socialno podjetništvo. Prav slednje predstavlja enega ključnih izzivov za trajnostni razvoj regije in krepitev sektorja NVO. Zlasti podeželje ima mnoge neizkoriščene potenciale, katerih aktivacija bi znatno pripomogla k ustvarjanju novih delovnih mest in višji kvaliteti življenja.

\section{Literatura}

Adam, F., in B. Rončević. 2004. »Razvojni potencial socialnega kapitala.« Družboslovne razprave 20 (4647): 219-237.

Adam, F., A. Hafner, D. Podmenik, D. Podmenik, U. Šinkovec, B. Rončević in A. Vojvodić. 2010. Inovativna jedra $v$ regionalnem razvoju. Ljubljana: Založba Vega.

Črnak-Meglič, A., in T. Rakar. 2009. "The Role of the Third Sector in the Slovenian Welfare System. "Teorija in praksa 46 (3): 237-254.

Črnak-Meglič, A., in M. Vojnovič. 1997. „Vloga in pomen neprofitno-volonterskega sektorja v Sloveniji.« Družboslovne razprave 13 (24-25): 152-178.

De Cooman, R., S. De Gieter, R. Pepermans in M. Jegers. 2011. "A Cross-Sector Comparison of Motivation-Related Concepts in For-Profit and Not-ForProfit Service Organizations.« Nonprofit and Voluntary Sector Quarterly 40 (2): 296-317.

Forbici, G., T. Divjak, B. Osonkar, V. Dernovšek in M. Verbajs. 2010. Skupaj za skupnost: priročnik o sodelovanju med občinami in nevladnimi organizacijami. Ljubljana: Zavod Center za informiranje, sodelovanje in razvoj nevladnih organizacij cNVOs.

Kolarič, Z. 1997. "Prostovoljne - neprofitne organizacije v Sloveniji.« Neprofitni management 1 (1): 17-20.

Kolarič, Z. 2002. »Različni znanstveno-teoretski pristopi k preučevanju neprofitnih organizacij. " $\mathrm{V} \mathrm{Ja}$ dranje po nemirnih vodah managementa nevladnih organizacij, ur. D. Jelovac, 29-44. Ljubljana: Radio Študent in Študentska organizacija Univerze; Koper: Visoka šola za management.
Leete, L. 2000. »Wage Equity and Employee Motivation in Nonprofit and for-Profit Organizations. « Journal of Economic Behavior \& Organization 43 (4): 423-446.

McCarthy, L. 2003. "The Good of the Many Outweighs the Good of the One: Regional Cooperation instead of Individual Competition in the United States and Western Europe? « Journal of Planning Education and Research 23 (2): 140-152.

Ministrstvo za gospodarski razvoj in tehnologijo. 2021. "Evidenca socialnih podjetij.«https://www.gov.si /assets/ministrstva/MGRT/Dokumenti/DRR /socialno-podjetnistvo/Evidenca-socialnih -podjetji_13.-7.-2021.xls.

Podmenik, D., B. Žižek, A. Hafner, Ž. Marčeta, B. Mevlja in N. Tominec. 2013. Analiza potencialov z akcijskim načrtom in ukrepi razvoja socialnega podjetništva na podeželju Slovenske Istre (LAS Istra). Koper: Zavod Eko-Humanitatis.

Potočnik Slavič, I. 2008. „Endogeni razvojni potenciali podeželja.« Doktorska disertacija, Univerza v Ljubljani.

Putnam, R. D. 1993. Making Democracy Work: Civic Traditions in Modern Italy. Princeton, NJ: Princeton University Press.

Rakar, T., T. Deželan, S. Š. Vrbica, Z. Kolarič, A. Črnak Meglič in M. Nagode. 2011. Civilna družba v Sloveniji. Ljubljana: Uradni list Republike Slovenije.

Središče Rotunda, primorski družbeni center. 2012. Strategija razvoja nevladnega sektorja v obalno-kraški regiji v obdobju 2013-2019. Koper: Središče Rotunda, primorski družbeni center.

Statistični urad Republike Slovenije. 2018. Regije v številkah: statistični portret slovenskih regij 2018. Ljubljana: Statistični urad Republike Slovenije.

Vrečko, I. 2003. Strategija sistemskega razvoja nevladnih organizacij v Sloveniji za obdobje 2003-2008. Ljubljana: Slovensko združenje za projektni management Slovenije.

Zakon o spodbujanju skladnega regionalnega razvoja (ZSRR-2). 2011. Uradni list Republike Slovenije, št. 20. https://www.uradni-list.si/1/objava.jsp?sop=201101-0820. 